\title{
First record of Mimagoniates inequalis (Eigenmann, 1911) (Characiformes: Characidae) from Argentina
}

\author{
María de las Mercedes Azpelicueta ${ }^{1^{*}}$ and Stefan Koerber ${ }^{2}$ \\ 1 CONICET- Museo de La Plata, Paseo del Bosque s/n, 1900 La Plata, Argentina. \\ 2 Friesenstr. 11, 45476 Muelheim, Germany. \\ * Corresponding author: azpeli@fcnym.unlp.edu.ar
}

\begin{abstract}
In the present note, we cite Mimagoniates inequalis from the río Paraná de las Palmas, close to Buenos Aires City. This record represents the first one for Argentina.
\end{abstract}

The characid genus Mimagoniates Regan, 1907 includes seven species defined by having a rudimentary or fully developed caudal-fin pump and the dorsal-fin origin posterior to a vertical through anal-fin origin. In the three basal species of the genus, including $M$. inequalis, the principal caudal-fin rays 11 and 12 are curved and enlarged and have a groove between them (Menezes and Weitzman 2009).

Mimagoniates barberi Regan, 1907, M. inequalis (Eigenmann, 1911), M. lateralis (Nichols, 1913), M. microlepis (Steindachner, 1877), M. pulcher Menezes and Weitzman, 2009, M. reocharis Menezes and Weitzman, 1990, and $M$. sylvicola Menezes and Weitzman, 1990, live in Atlantic affluents between Bahia (Brazil) and Uruguay, in the upper río Paraguay, the upper río Iguazú, and the middle and upper río Paraná. The southernmost limit of the geographic distribution of the genus is reported from the Humedales del Este, Departamento Rocha, Uruguay, in small ponds and streams flowing into the Atlantic Ocean, where M. inequalis was collected by Azpelicueta and García (2001) in the surroundings of the Laguna de Castillos (34²18' S, 535' W). Mimagoniates inequalis was also recorded from tributaries of the upper río Negro, in Rivera, Uruguay (Menezes et al. 2008), a locality corresponding to the basin of the río de la Plata (Figure 1). Mantinian and Miquelarena (2010) found $M$. barberi in two different localities in the Paraná River basin, Misiones, Argentina.

The objective of this paper is to report $M$. inequalis from the río Paraná de las Palmas, west of the city of Buenos Aires (Figure 1). This record is the first of this species from Argentina, the first from the Paraná basin and the so far only the second record of the species from the Río de la Plata basin.

Mimagoniates inequalis is distinguished from other species of the genus by the presence of 26-30 branched anal-fin rays, 34-41 scales in the lateral line, 15-18 scale rows between dorsal-fin origin and anal-fin origin, and the dorsal fin closer to caudal-fin base than to tip of snout.
The measurements and counts of six adults are presented in Table 1. Measurements and counts were taken following Menezes and Weitzman (1990). Percentages of different values in SL or HL have similar values to those presented by Menezes and Weitzman (2009). These authors mentioned 2.8-3.0 for the body depth at dorsalfin origin; the specimens examined have scarcely low body (3.0-3.22). Counts of scales are as follows: Scales in the lateral series 36-38, predorsal scales 17-18, scales between dorsal-fin and pelvic-fin origins 13-15, scale rows around caudal peduncle 15-16; counts are similar to the values presented by Menezes and Weitzman (2009). We did not found differences between males and females. Counts of fin rays: Dorsal fin ii,8-9, anal fin iv,25-29, pectoral fin i,6-7,

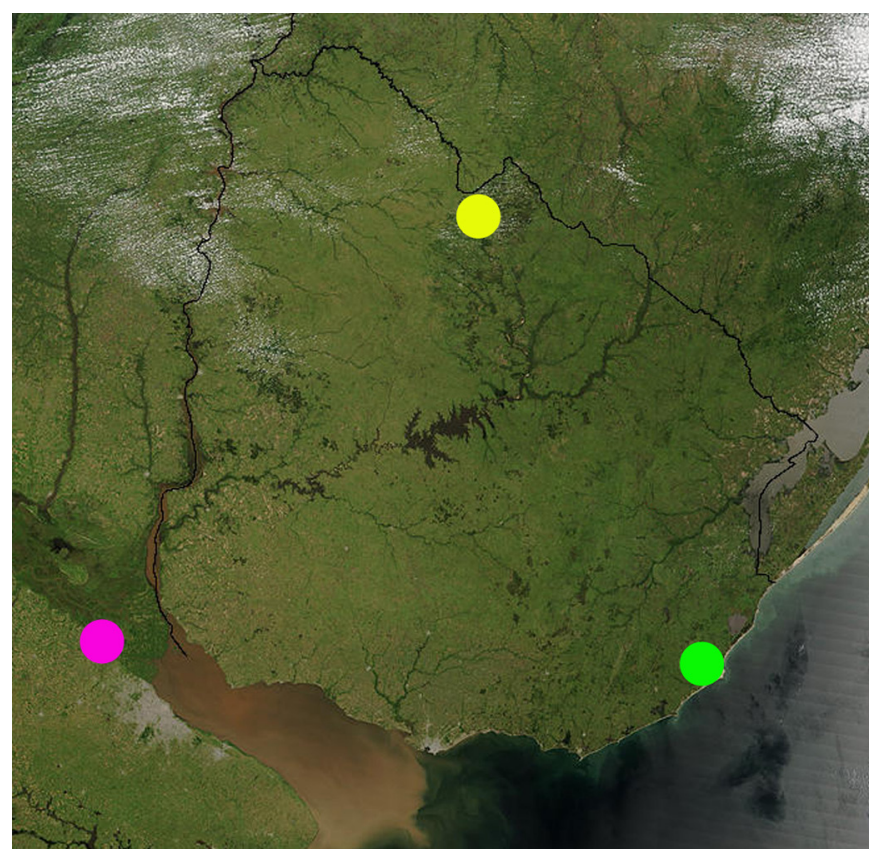

FIGURE 1. Collection sites of Mimagoniates inequalis as mentioned: the new locality in Argentina (magenta); Rivera, Uruguay (yellow), and the Laguna de Castillos, Uruguay (green). Satellite image was taken from Wikipedia, dots were added. 


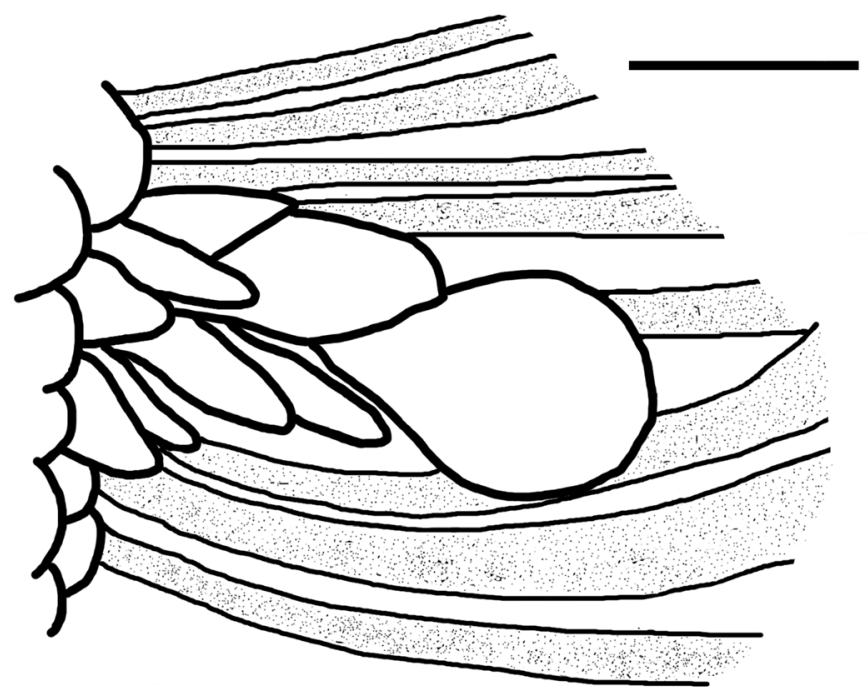

FIGURE 2. Mimagoniates inequalis, distribution of caudal scales in male; note the curvature of the caudal-fin rays 11-12.

pelvic fin i,6-7; when seven rays are present, the last one is unbranched.

The largest male has one pair of hooks per ray in the last unbranched and first six branched anal-fin rays, excluded the first branched ray which has two pairs of hooks. The squamation of the caudal fin is slightly modified compared with other species; the caudal-fin rays 11 and 12 are curved dorsally (Figure 2). The pigmentation pattern of $M$. inequalis does not possess striking features. A black, somewhat rounded humeral spot is present in both sexes, also a slender black stripe extends from posterior portion of head to the end of caudal peduncle and a slender middorsal black stripe is present; in males, the anal fin has a black, distal band, and many chromatophores bound the upper and lowermost caudal-fin rays. Males in aquarium have the dorsum of the body greenish or faint yellowish (Figure 3).

A group of juveniles, then unrecognized, belonging to $M$. inequalis was collected by the authors in the lower basin of the río Paraná. The collection site (Figure 4) is a southern side channel of the río Paraná de las Palmas, the Southern branch of the Paraná river in its delta, on the road from the city of Escobar to the village of Paraná de
TABLE 1. Measurements of six specimens of Mimagoniates inequalis from the Río de la Plata basin, in Argentina.

\begin{tabular}{lccc}
\hline & MEAN & MIN & MAX \\
\hline SL & & 25.56 & 33.32 \\
Percentage of SL & & & \\
Depth at dorsal-fin origin & 31.86 & 31.59 & 32.19 \\
Snout to dorsal-fin origin & 56.32 & 54.34 & 58.75 \\
Snout to pectoral-fin origin & 25.82 & 24.40 & 26.62 \\
Snout to pelvic-fin origin & 42.31 & 40.38 & 43.83 \\
Snout to anal-fin origin & 55.15 & 53.11 & 57.10 \\
Caudal peduncle depth & 13.15 & 12.00 & 14.82 \\
Caudal peduncle length & 11.71 & 11.10 & 12.18 \\
Pectoral-fin length & 23.35 & 22.50 & 24.57 \\
Pelvic-fin length & 14.03 & 13.75 & 14.55 \\
Dorsal-fin base length & 15.81 & 14.78 & 17.10 \\
Dorsal-fin height & 20.13 & 19.30 & 21.84 \\
Anal-fin base length & 36.95 & 35.29 & 38.41 \\
Anal-fin lobe length & 17.72 & 16.65 & 18.39 \\
Dorsal-fin/caudal-fin base & 44.61 & 43.11 & 46.27 \\
Bony head length & 24.63 & 23.32 & 26.69 \\
Percentage of HL & & & \\
Eye diameter & 37.70 & 36.01 & 39.70 \\
Snout length & 21.44 & 19.90 & 22.96 \\
Least interorbital width & 37.43 & 33.85 & 41.80 \\
Upper jaw length & 45.98 & 44.93 & 47.77 \\
\hline
\end{tabular}

las Palmas ( $\left.34^{\circ} 16^{\prime} 05^{\prime \prime} \mathrm{S}, 58^{\circ} 43^{\prime} 16^{\prime \prime} \mathrm{W}\right)$. The dead end of the channel has been enlarged by local neighbors in order to turn around their boats there, forming now a small bay, where wind and current gather leafs and driftwood. A mix of juvenile characiforms, all below $20 \mathrm{~mm}$, of several species was caught between these drifting structures with a square net. Only after growing for a couple of months in aquarium, animals from this locality could be identified alive tentatively as $M$. inequalis and six were preserved for determination. Material examined: Asociación Ictiológica, La Plata, AI 304, 3 ex., 27.49-33.32 mm SL; Fundación Miguel Lillo, CI-FML 5309, 3 ex., 29.37$25.56 \mathrm{~mm}$ SL.

The same site was fished again one year later and both catches together give a basic idea of the ichthyofaunal composition of this habitat: Astyanax sp., Charax

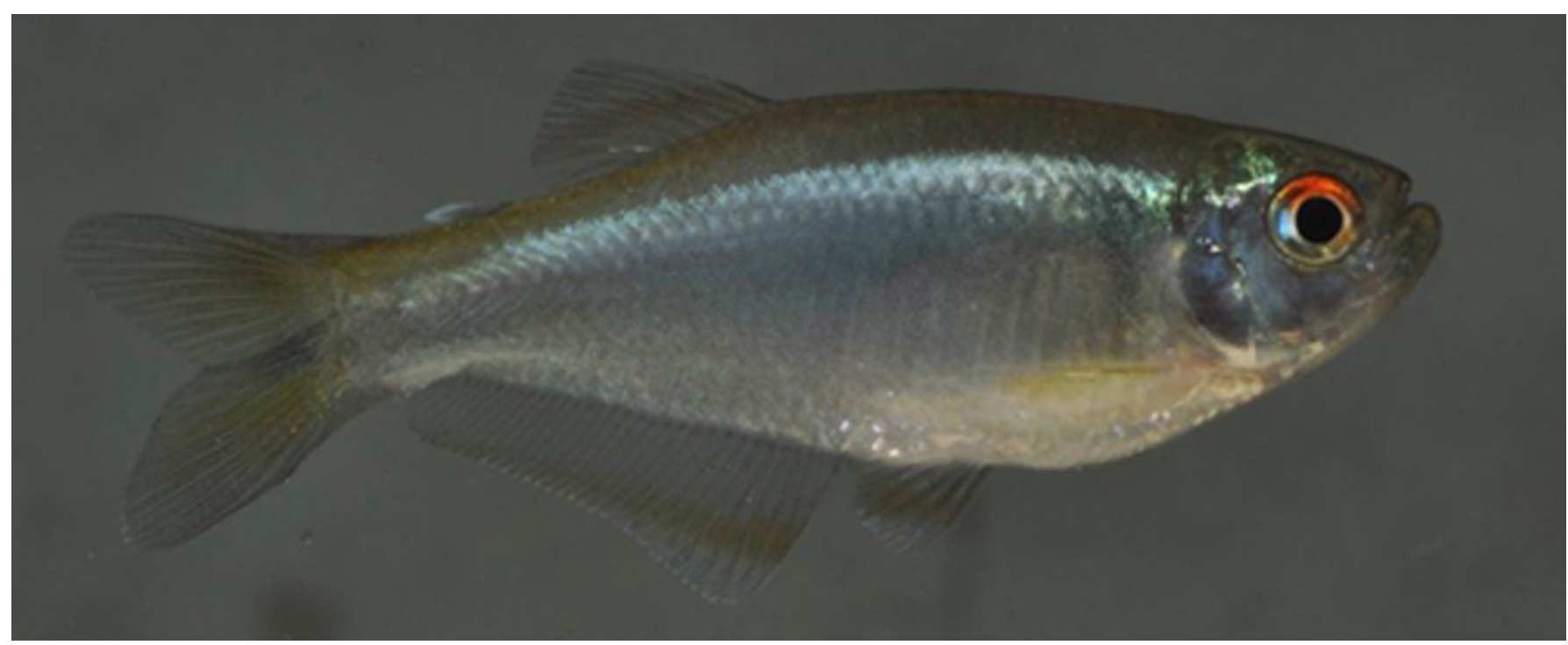

FIGURE 3. Mimagoniates inequalis, male from the new locality in aquarium (not preserved) 
stenopterus, Cnesterodon decemmaculatus, Cynopotamus argenteus, Hisonotus sp., Hoplias malabaricus, Mylossoma duriventre, Oligosarcus sp., Rineloricaria sp., Salminus brasiliensis, Sorubim lima (26Nov2009); Astyanax sp., Cheirodon interruptus, Cnesterodon decemmaculatus, Leporinus obtusidens, Phalloceros caudimaculatus, Pimelodus sp., Prochilodus lineatus, Rineloricaria sp., Salminus brasiliensis (29Nov2010).

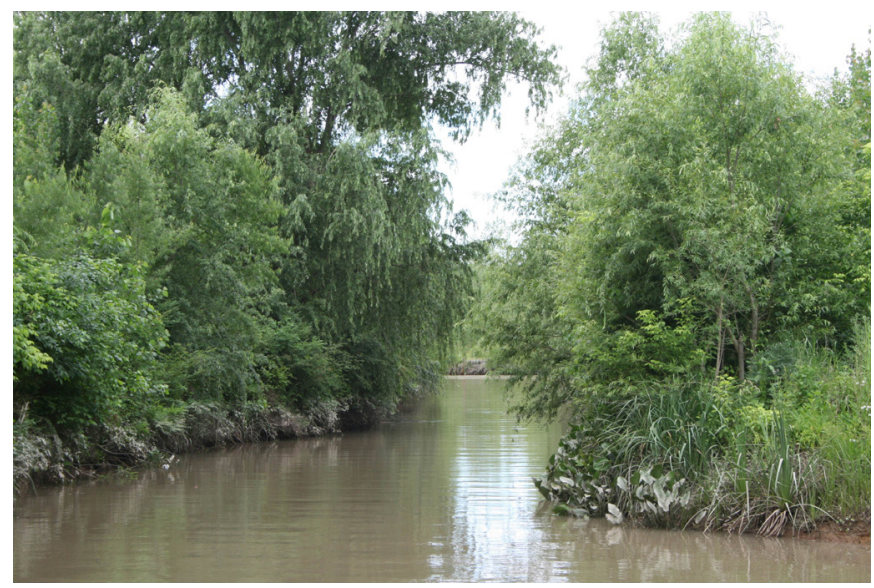

FIGURE 4. First collection site of Mimagoniates inequalis in Argentina: channel in the Tigre delta, looking westward.
ACKNOWLEDGMENTS: The authors thank Osvaldo Fernandez Santos, Pedro Heinonen and Claudio Schilling for their help in the field. Sascha Thamm helped us with his extraordinary skills and advice in growing up and curing from parasites of juvenile wild specimens. Thanks are due to Wikipedia for making the satellite image available to the public.

\section{LITERATURE CiTED}

Azpelicueta, M.M. and G. García. 2001. The fish fauna of a reserve of biosphere, the "Humedales del Este", in Uruguay. Biogeographica 77(1): 1-13.

Mantinian, J.E. and A.M. Miquelarena. 2010. Pisces, Characiformes, Characidae, Glandulocaudinae, Mimagoniates barberi Regan, 1907: First Argentinean distribution record. Check List 6(3): 416-418.

Menezes, N.A. and S.H. Weitzman. 1990. Two new species of Mimagoniates (Teleostei: Characidae: Glandulocaudinae), their phylogeny and biogeography and a key to the glandulocaudin fishes of Brazil and Paraguay. Proceedings of the Biological Society of Washington 103(2): 380-426.

Menezes, N.A. and S.H. Weitzman. 2009. Systematics of the Neotropical fish subfamily Glandulocaudinae (Teleostei: Characiformes: Characidae). Neotropical Ichthyology 7(3): 295-370.

Menezes, N.A., A.C. Ribeiro, S.H. Weitzman and R.A. Torres. 2008. Biogeography of Glandulocaudinae (Teleostei: Characiformes: Characidae) revisited: phylogenetic patterns, historical geology and genetic connectivity. Zootaxa 1726: 33-48.

RECEIVED: March 2012

ACCEPTED: June 2012

PUBlished ONLINE: August 2012

EDITORIAL RESPONSIBILITY: Sergio Maia Queiroz Lima 